\title{
Factors Influencing Visitors' Revisit Behavioral Intentions: A Case Study of Sabah, Malaysia
}

\author{
Ahmad Puad Mat Som ${ }^{1}$, Azizan Marzuki ${ }^{1}$, Maryam Yousefi ${ }^{1}$ \& Ala`a Nimer AbuKhalifeh ${ }^{1}$ \\ ${ }^{1}$ School of Housing, Building and Planning, Universiti Sains Malaysia, Penang, Malaysia \\ Correspondence: Ahmad Puad Mat Som, School of Housing, Building and Planning, Universiti Sains Malaysia, \\ 11800 Penang, Malaysia. Tel: 60-4-653-3741.E-mail: puad@usm.my or puadusm@gmail.com
}

\author{
Received: March 3, 2012 Accepted: May 16, 2012 Online Published: July 25, 2012 \\ doi:10.5539/ijms.v4n4p39 URL: http://dx.doi.org/10.5539/ijms.v4n4p39
}

\begin{abstract}
Revisit intention has been highlighted as an important research topic in competitive market of tourism destinations. Despite the considerable number of research on repeat visitors, it remains unclear why people undertake repeat visits and what kind of characteristics hold repeat visitors. This research aims to identify factors influencing repeat visitors to Sabah, Malaysia. The results of this study indicated that "destination image" and "relaxation and recreation" were the most important destination attributes and travel motives for repeat visitors to Sabah. Concerning their perception on destination loyalty, the study revealed that respondents were loyal to Sabah, intent to revisit and recommended Sabah as a holiday destination.
\end{abstract}

Keywords: revisit behavioral intentions, destination loyalty, relationship marketing, Sabah

\section{Introduction}

Tourism scholars have concentrated on repeat visitation as an antecedent of destination loyalty. Some empirical studies have acknowledged that many tourist destinations rely seriously on repeat visitors (e.g., Darnell \& Johnson, 2001; Jayaraman et al., 2010). In this sense, previous researches have examined factors influencing tourist behavior towards a repeat visitation. In tourism, major antecedents of revisit intention such as satisfaction (Baker \& Crompton, 2000; Frochot \& Hughes, 2000; Kozak, 2001, 2003; Petrik et al., 2001; Yuksel, 2001; Fuchs \& Weiermair, 2003; Fallon \& Schofield, 2003; Li \& Carr, 2004; Jang \& Feng, 2007), novelty seeking (Jang \& Feng, 2007), perceived value (Petrik et al., 2001; Um et al., 2006; Chen \& Tsai, 2007; Bigne et al., 2009), past vacation experience (Chen \& Gursoy, 2001; Kozak, 2001; Petrik et al., 2001), safety (Chen \& Gursoy, 2001), cultural differences (Reisinger \& Turner, 1998; Chen \& Gursoy, 2001), image (Ross, 1993; Milman \& Pizam, 1995; Yoon \& Uysal, 2005, Chi \& Qu, 2008), motivation and satisfaction (Yoon \& Uysal, 2005), and destination attributes (Akama, 2003; Chi \& Qu, 2008; Zabkar et al., 2010) have been identified by various researchers.

Chen \& Tasi (2007) assert that "by understanding the relationships between future behavioral and its determinants, destination tourism managers would know better on how to build up an attractive image and improve their marketing efforts to maximize their use of resources" (p. 1116). Study on repeat visitation is vital for tourism businesses from the economic perspective. Attracting previous customers is more cost-effective than gaining new ones (Shoemaker \& Lewis, 1999). In tourism, the promotional costs of attracting repeat visitors are less than first time visitors (Weaver \& Lawton, 2002; Lau \& Mckercher, 2004). Moreover, preserving loyal customers is a crucial contributor to the profitability of business (Hsu et al., 2008). According to Mat Som et al. (2011, p.178), "previous studies show 2\% increase in customer retention has the same effects on profits in terms of cost cutting by $10 \%$ ".

From Jang and Feng's perspective (2007), repeat visitors are significant in increasing revenue in tourism destinations and in saving marketing dollars. Similarly, Jayaraman et al. (2010) mentioned that repeat visitors to Malaysia are imperative for increasing revenue of tourism industry. Hence, the critical analysis and in- depth study on the factors influencing repeat visitors may provide the ground to improve the Malaysian tourism market for repeat visitors. The purpose of this study is to identify the key factors that affect repeat visitors in Sabah. First, this paper presents a breif review of litreature regarding revisit intention and destination loyalty from relationship marketing perspective. Second, it outlines the research methodology, and finally the findings of the research is presented. 


\section{Relationship Marketing}

"The globalization of markets, competitive presure, brand multiplication and, above all, the ever-changing lifestyles and consumer behavior have forced companies to develop strategies to keep their clients and create consumer loyalty programmes and thus carry out relationship marketing" (Flambard-Ruaud, 2005, p. 55). "The definition of marketing has changed from purely transaction driven to being process driven. The transaction-focused view of marketing is being challenged because: (i) the short term focus of many marketing practices has failed to serve customers' best interests, and (ii) corporate self-interest has not been served because attraction is more expensive than retention" (Nwakanma et al., 2007, p.57).

Marketing is no longer simply about developing, selling, and delivering product, it is more concerned with the developement and maintenence of mutually satisfying long-term relationship with customers (Buttle, 1996). The new definition realizes the value of lifetime customer and the importance of preventing customer defection. "In this new perspective, both transactional and relational qualities are combined and strive to establish, maintain, and enhance mutually beneficial relationship with customers so as to satisfy the objectives of all parties" (Nwakanma et al., 2007, p.57).

Relationship marketing is acknowledged by academics and practitioners as "a competitive strategy aimed at the creation, maintenance and developement of sucessful relationship with customers, and it is currently considered a management approach to cover all marketing activities and generate important advantages in its implementation, both in firms and for customers" (Casielles et al., 2005, p. 83). In tourism, "relationship marketing is regarded as an apt strategy and coherent approch to building a continuous relationship among all key elements (e.g., stakeholders, host community, tourists) in tourism destination to gain competitive advantages"(Mostafavi Shiazi \& Mat Som, 2010, p.48). "Building a strong customer relationship offers a significant competitive advantage due to difficulty of direct imitation by competitors" (Sherrell \& Beju, 2007, p. 4).

Fally et al. (2003) mention that "with increasing global competition owing to newly-emerging destinations, tourists becoming more exacting in their choice and desire for a variety of options; relationship marketing arguably offers considerable potential to achieve advantage" (p. 645). It is important to note that the primary goal of relationship marketig is loyalty and sometimes even equated with relationship marketing concept itself (Boonajesevee, 2005). Significantly, the benefits of relationship marketing in competitive market are recognized as: gaining comptetive advantages, preparing long-term profitability, reducing market research, and creating loyal customers (Lovelock et al., 1996). It is imprtant to note that relationship marketing is considered as a competitive strategy aimed at creating long term relationship and improving corporate performance through customer loyalty (Mostafavi Shirazi \& Mat Som, 2011). In competitive market of tourism destination, the focal point of relationship marketing that has been highlighted is creating loyal visitors for future action intention (ibid).

\subsection{Destination Loyalty}

Destination loyalty has recieved considerable attention from academics and practitioners as an important benchmark for developing useful business strategy (Shanka et al., 2010). Scholars have paid attention to the distinctiveness of different concepts for destination loyalty, the ways of its measurment and the influence on the ultimate result (Lee et al., 2004). Understanding the antecedents of loyalty allows destination operators to concentrate on factors which leads to visitors' retention over the time. Reviewing more than 25 emprical studies, Shanka et al. (2010) found that different authors used more than 30 factors in different research settings as antecedents or evaluative factors for loyalty. Lee et al. (2004) showed direct relationship between service quality and satisfaction and identified satisfaction as antecedent of loyalty. In another study on Cox's Bazar in Bangladesh, perceived satisfaction was found as the main antecedent of destination loyalty (Shanka et al., 2010). In Campo \& Yague's study (2008), price was identified as the antecedent of quality, quality as antecedent of satisfaction, and satisfaction as the anticident of loyalty.

Yoon \& Uysal (2005) assert that "in an increasingly competitive marketplace, the success of marketing destinations should be guided by a through analysis of tourist motivation and its interplay with tourist satisfaction and loyalty" (p.45). In their model, motivation is divided into push and pull factors. Push factors are socio-psychological needs which relate to intrinsic motivators, while pull factors are external forces that relate to attractiveness and specific features of the destination. Their results showed that both push and pull factors affect destination loyalty. They argued that motivation in behavioral researches need further domains other than examining tourists' wants and needs. 
In Prayag \& Ryan' view (2011, p. 3), “it is generally accepted that pull factors are measured via lists of destination attributes that represent place perceptions". Moreover, a critical relationship between push/pull motivation and destination loyalty in terms of revisit intention and recommendation has been underlined by previous studies (e.g., Yoon \& Uysal, 2005). In reviewing litreatures, "revisit intention" and "positive word of mouth recommendation" have been recognized as indicators of loyalty in many studies (Bigne et al., 2001; Chen \& Gursoy, 2001; Niininen et al., 2004; Yoon \& Uysal, 2005; Chi \& Qu, 2008).

\subsection{Revisit Intention}

From consumption process's perspective, tourists' behavior is divided into three stages including: pre-visitation, during visitation, and post visitation (Rayan, 2002; William \& Buswell, 2003). Chen \& Tsai (2007) stated that tourists' behaviors include choice of destination to visit, subsequent evaluations, and future behavioral intentions. The subsequent evaluations are the travel experience or percived value and overall visitors' satisfaction, whereas the future behavioral intentions refer to the visitor's judjment about the likeliness to revisit the same destination and willingness to recommend it to others.

Several studies identified satisfaction with travel experience as the major antecedent of revisit intention (Oppermann, 2000; Baker \& Crompton, 2000; Petrik et al., 2001; Kozak, 2001; Jang \& Feng, 2007; Alexandris et al., 2006; Chi \& Qu, 2008), and positive satisfaction has a positive influence on tourists' repurchase intention (Gotlieb et al., 1994). In contrast, Um et al. (2006) found that satisfaction was insignificant in affecting revisit intention to Hong Kong for European and North American tourists. Beigne et al. (2009) argued that in competitive market even satisfied customer may switch to rival because of the opportunities to achive better results. In another view, Cronin et al. (2000) state that perceived value may be a better predictor of repurchase intention than either satisfaction or quality.

Zabkar et al. (2010) explored complex relationship between main constructs and behavioral intentions. Based on their model, destination attributes affect perceived quality which then affects satisfaction, the latter lead to revisit intention. From Jang \& Feng's perspective (2007), novelty seeking is highlighted as an antecedent of revisit intention. They examined the effects of tourists' novelty-seeking and destination satisfaction on revisit intentions in short-term, mid-term, and long-term. They found that satisfaction influence tourists' intention for revisit in short-term, while novelty-seeking influence tourists' intention for revisit in mid-term, and long term. Petrik (2002) suggested that "novelty seeking" play an important role in tourists' decision making process. Pearson (1970) described novelty seeking as the level of contrast between current perception and past experience. In tourism, novelty seeking is also investigated as an enhancer for tourist's satisfaction (Crotts, 1993).

Mostafavi Shirazi \& Mat Som (2010) examined the effect of destination attributes on revisit intention in Penang. They found repeat visitation as an indicator of loyalty in tourist destination that is strongly affected by destination attributes. In their study, diversification of attractions has been found as one of the necessary conditions for explaining repeat visitations (ibid). Many studies have pointed out the relationship between image and destination loyalty (Rittchainuwat et al., 2001; Ross 1993; Tasci \& Gartner, 2007; Wang et al., 2011). In this sense, Chi \& Qu (2008) underlined 'destination image' as an antecedent of destination loyalty.

It is generally accepted that destination image has influenced tourist behaviors (Lee et al., 2005; Bigne et al., 2001). In many studies, destination image is distinguished as a destination attribute and is considered as an effective tool to attract tourists (Kneesel et al., 2010). Bigne et al. (2001) and Lee et al. (2005) have emphasized that destination image plays two crucial roles in behaviors: first, influence the destination choice decision-making process, and second, influence conditions after decision-making behaviors (intention to revisit and willingness to recommend).

Acorrding to Lee et al. (2005), individual with a more favorable destination image perceived higher on site experience, that led to higher satisfaction and the more positive behavioral intentions. Chen \& Tsai (2007) tested the relationship between destination image, evaluative factors (e.g., trip quality, perceived value, satisfaction) and behavioral intentions. They found that destination image and satisfaction were two important variables that influenced visitors' behavioral intention. Thier study revealed that destination image influenced behavioral intentions directly and indirectly.

\subsection{Recommendation to Others}

Shanka et al. (2002) confirm the positive effect of word of mouth information for destination selection. Recommendation to other people is one of the most often sought types of information for people interested in traveling" (Chi \& Qu, 2008, p. 625). Word of mouth recommendations are especially critical in tourism 
marketing because they are considered to be the most reliable, and thus are one of the most sought-after information sources for potential tourists (Yoon \& Uysal, 2005). Similarly, Wong \& Kwong (2004) mentioned that repeated visitors increase word-of-mouth and such recommendation effects on potential visitors. Notably, Hui et al. (2007) argue that tourists who were satisfied from the whole trip were likely to recommend the destination to others rather than to revisit it in the future. Although a number of studies have been conducted to identify antecedents of destination loyalty (revisit intention and recommendation), there is no general agreement among scholars regarding the antecedents of revisit intention.

\section{Research Methodology}

A self-administered survey questionnaire was developed to identify factors influencing repeat visitation to Sabah. The target population of this study was international tourists. The survey instrument was mainly aimed at identifying the underlying dimensions of visitors' revisit intention. A convenience sampling approach was employed to collect data in April 2011 at both terminals of Kota Kinabalu International Airport in Sabah. Among 150 self-administered questionnaires distributed, a total of 105 usable questionnaires were obtained representing $70 \%$ of response rate. A five-part self-administered survey focused on travel characteristics, destination attributes, travel motives, tourists' perception on destination loyalty, and demographic variables of the respondents. The first part posed questions on travel characteristics including number of visits, purpose of visits, length of stay, travel companion, source of information, transportation, type of accommodation, and tourism type. In the second part, respondents were asked to indicate their agreement with statements about destination attributes to revisit Sabah. The attribution items were assessed, using a 5-point Likert scale from $5=$ strongly disagree to $1=$ strongly agree. In the third part of the questionnaire, respondents were asked to indicate their agreement with statements describing their motives for revisiting Sabah. Likewise, in the subsequent part, respondents' perceptions on destination loyalty were assessed. The last part posed questions on respondents' background; the demographic profiles included age, gender, marital status, income, education, and occupation. Data were analysed using SPSS version 17.0 in three steps. First, the findings were profiled by socio-demographic and travel characteristics. Second, a factor analysis using principal component method with Varimax rotation was run to identify underlying dimensions of each set of 19 destination attributes and 23 motivational items. Finally, descriptive statistics were used to compute the mean scores for each of tourists' perceptions on destination loyalty items.

\section{Research Findings}

\subsection{Respondents' Demographic Characteristics}

The findings indicated that the majority of respondents were males (61\%), married (57.1\%), between the age of 21 to 30 years old $(29.5 \%)$, bachelor degree holders (36.2\%), and professional (59.6\%). Most of respondents declared to earn less than 80,000 USD per annum $(66.9 \%)$.

Table 1. Demographic profiles of respondents

\begin{tabular}{lll}
\hline Variables & Desscriptions & Percentage \\
\hline Gender & Male & 61 \\
Age & Female & 39 \\
& 20 years and below & 2.9 \\
& $21-30$ & 29.5 \\
& $31-40$ & 28.6 \\
& $41-50$ & 15.2 \\
Marital Status & $51-60$ & 17.1 \\
& Over 60 & 6.7 \\
Annual Income (USD) & Single & 28.6 \\
& Married & 57.1 \\
& Widowed & 2.9 \\
& Others & 11.4 \\
& Less than $\$ 20,000$ & 16.5 \\
& $\$ 20,001-40,000$ & 18.4 \\
& $40,001-60,000$ & 13.6 \\
& $\$ 60,001-80,000$ & 18.4 \\
& $\$ 80,001-100,000$ & 19.5 \\
\hline
\end{tabular}




\begin{tabular}{lll}
\hline Education level & Secondary school & 11.4 \\
& Diploma & 22.9 \\
Bachelor & 36.2 \\
Master & 20 \\
PhD & 6.7 \\
Occupation & 2.8 \\
& Others & 59.6 \\
& Goversional & 5.8 \\
& Private sector employee & 13.5 \\
Self employed & 4.8 \\
Business owner & 1 \\
Retiree & 3.8 \\
& House wife & 2.9 \\
Student & 1.9 \\
\hline
\end{tabular}

\subsection{Travel Characteristics}

The results of travel characteristics revealed that $42.9 \%$ of respondents visited Sabah for the second time, used internet to obtain information about Sabah (62.2\%), stayed in Sabah more than one week (46.5\%), and the main purpose of their visit was leisure $(70.5 \%)$. The findings also showed that most of the respondents were eco-tourists $(64.8 \%)$, travel to Sabah by air $(92.3 \%)$, with their spouse (41.9\%), stayed at $4-5$ stars hotels/resorts $(55.8 \%)$, and used air plane to travel within Malaysia (see Table 2).

Table 2. Travel characteristics

\begin{tabular}{|c|c|c|}
\hline Variables & Desscriptions & Percentage \\
\hline \multirow[t]{5}{*}{ Number of visits } & 2 times & 42.9 \\
\hline & 3 times & 14.3 \\
\hline & 4 times & 8.5 \\
\hline & 5 times & 3.8 \\
\hline & More than 5 times & 30.5 \\
\hline \multirow[t]{4}{*}{ Purpose of visit } & Leisure & 71.8 \\
\hline & Business & 11.7 \\
\hline & Visiting friends/relatives & 8.7 \\
\hline & Others & 7.8 \\
\hline \multirow[t]{7}{*}{ Length of stay } & 1 night & 4.8 \\
\hline & 2 nights & 6.7 \\
\hline & 3 nights & 5.7 \\
\hline & 4 nights & 5.6 \\
\hline & 5 nights & 1 \\
\hline & 6 nights & 10.5 \\
\hline & More than a week & 65.7 \\
\hline \multirow[t]{8}{*}{ Travel companion/s } & Alone & 21.9 \\
\hline & With my spouse & 41.9 \\
\hline & With my family & 13.3 \\
\hline & With friends & 7.6 \\
\hline & With relatives & 3.8 \\
\hline & With business associates & 3.8 \\
\hline & With a tour group & 6.7 \\
\hline & Others & 1 \\
\hline \multirow[t]{6}{*}{ Source of information } & Pervious trip(s) & 47.6 \\
\hline & Internet & 58.1 \\
\hline & Brochures & 14.3 \\
\hline & Travel guidebooks & 41 \\
\hline & Travel agencies & 14.3 \\
\hline & Tourist information centers & 4.8 \\
\hline
\end{tabular}


Transportation

\section{Transportation within Malaysia}

\section{Type of accommodation}

\section{Tourism type/s}

\begin{tabular}{|c|c|}
\hline Words of mouth & 33.3 \\
\hline Travel expo/exhibitions & 1.9 \\
\hline Others & 3.9 \\
\hline Air & 92.3 \\
\hline Sea & 1 \\
\hline Road & 6.7 \\
\hline \multicolumn{2}{|l|}{ Train } \\
\hline Air plane (premium airline(s) & 60.6 \\
\hline Air plane (low cost airline(s) & 36.5 \\
\hline Private car & 11.7 \\
\hline Rented car & 15.3 \\
\hline Bus/Coach & 33.6 \\
\hline Van & 8.8 \\
\hline Train & 8 \\
\hline Taxi & 49.6 \\
\hline Cruise ship & 2.2 \\
\hline Motorcycle & 2.2 \\
\hline Others & 10.2 \\
\hline High range hotel/resort (4-5star) & 55.8 \\
\hline Mid-range hotel/resort (3 star) & 22 \\
\hline Low cost hotel/resort (1-2 star) & 4.8 \\
\hline Serviced apartment/condominium & 1 \\
\hline Guest house & 7.7 \\
\hline Home stay & 5.8 \\
\hline Others & 2.9 \\
\hline Ecotourism/Nature tourism & 64.8 \\
\hline Highland tourism & 6.7 \\
\hline Event tourism & 2.9 \\
\hline Rural tourism & 18.1 \\
\hline Urban tourism & 25.7 \\
\hline MICE tourism & 100 \\
\hline Agro tourism & 2.9 \\
\hline Heritage tourism & 27.6 \\
\hline Sport tourism & 7.6 \\
\hline Island/coastal tourism & 46.7 \\
\hline Cultural tourism & 28.6 \\
\hline Medical tourism & 1.9 \\
\hline Adventure tourism & 25.7 \\
\hline Educational tourism & 5.7 \\
\hline Others & 6.7 \\
\hline
\end{tabular}

\subsection{Factor Analysis of Destination Attributes}

To identify the underlying dimensions of destination attributes of repeat visitors, a principal component factor analysis was carried out to group the destination attribute items with common characteristics. The Barlett's Test of Sphericity shows statistical significance with the Kaiser-Meyer-Olkin value of .835, exceeding the recommended value of 0.6 (Hair et al., 1995). Reliability analysis (Cronbach's alpha) was calculated to test the reliability and internal consistency of each factor and a cut-off point of 0.4 was used to include items in interpretation of a factor.

Table 3 reports that the factor analysis of 19 destination attributes resulted in three factor groupings, which accounted for $68.68 \%$ of variance. The factor groupings of destination attributes were "destination image", "modern environment", and "weather \& natural attractions". "Destination image" was the most important destination attribute for repeat tourists which explained $44.13 \%$ of the varience (eigenvalue is 5.29). 
Table 3. Principal components of destination attributes

\begin{tabular}{|c|c|c|c|c|c|c|}
\hline Statements & Factor loading & Cummunalities & Eigenvalue & Variance & Mean & $S D$ \\
\hline Destination Image & & & 5.29 & $44.13 \%$ & 3.84 & .679 \\
\hline $\begin{array}{l}\text { Malaysia as a "Truly } \\
\text { Asia" destination }\end{array}$ & 0.674 & .539 & & & & \\
\hline Friendly local people & 0.809 & .748 & & & & \\
\hline $\begin{array}{l}\text { Rich diversity of local } \\
\text { food }\end{array}$ & 0.855 & .743 & & & & \\
\hline $\begin{array}{l}\text { English is widely } \\
\text { spoken among local } \\
\text { people }\end{array}$ & 0.755 & .643 & & & & \\
\hline $\begin{array}{l}\text { Good value for money } \\
\text { destination }\end{array}$ & 0.673 & .622 & & & & \\
\hline Modern Environment & & & 1.85 & $15.43 \%$ & 3.52 & .683 \\
\hline $\begin{array}{l}\text { Economically } \\
\text { developed country }\end{array}$ & 0.788 & .743 & & & & \\
\hline $\begin{array}{l}\text { Modern and advanced } \\
\text { country }\end{array}$ & 0.798 & .726 & & & & \\
\hline $\begin{array}{l}\text { Progressive Islamic } \\
\text { country }\end{array}$ & 0.756 & .629 & & & & \\
\hline $\begin{array}{l}\text { Country with excellent } \\
\text { transportation system }\end{array}$ & 0.778 & .628 & & & & \\
\hline $\begin{array}{l}\text { Weather \&Natural } \\
\text { Attraction }\end{array}$ & & & 1.09 & $9.11 \%$ & 3.96 & .768 \\
\hline A tropical destination & 0.739 & .685 & & & & \\
\hline $\begin{array}{l}\text { Country with pleasant } \\
\text { weather \& climate }\end{array}$ & 0.820 & .768 & & & & \\
\hline $\begin{array}{l}\text { Rich in mega diversity } \\
\text { of natural resources }\end{array}$ & 0.823 & .767 & & & & \\
\hline Total Variance & $68.68 \%$ & & & & & \\
\hline
\end{tabular}

\subsection{Factor Analysis of Motives}

The same procedure was applied for 23 motivational items to delineate underlying dimensions associated with repeat tourists' motives. All factors had an eigenvalue greater that one. The composite reliability test indicated that the reliabilitiy coefficient for motive factors stood at 0.74 . Table 4 reports that factor analysis of 23 motives items results in 5 factor groupings, which accounted for $70.26 \%$ of the variance. The factor grouping of motives factors are "relaxation \& recreation", "enhance relation", "enhance social", "fullfiling prestige", and "escaping from the daily routine". "Relaxation \& recreation" was the most important motive to revisit Sabah. This factor explained $28.44 \%$ of variance (eignvalue is 5.12 ).

Table 4. Principal components of motives

\begin{tabular}{|c|c|c|c|c|c|c|}
\hline Statements & $\begin{array}{l}\text { Factor } \\
\text { loading }\end{array}$ & $\begin{array}{l}\text { Cummun } \\
\text { alities }\end{array}$ & $\begin{array}{l}\text { Eigenv } \\
\text { alue }\end{array}$ & Variance & Mean & $S D$ \\
\hline Relaxation \& Recreation & & & 5.12 & $28.44 \%$ & 3.39 & .790 \\
\hline To relax physically & .608 & .558 & & & & \\
\hline To relax spiritually & .809 & .749 & & & & \\
\hline To participate in new activities & .832 & .740 & & & & \\
\hline To find thrills and excitement & .669 & .662 & & & & \\
\hline To sightseeing touristic spots & .726 & .688 & & & & \\
\hline To appreciate natural resources & .711 & .699 & & & & \\
\hline Enhance Relation & & & 2.90 & $16.16 \%$ & 3.05 & .810 \\
\hline To meet new people & .750 & .692 & & & & \\
\hline $\begin{array}{l}\text { To enhance communication with local } \\
\text { community }\end{array}$ & .755 & .671 & & & & \\
\hline
\end{tabular}




\begin{tabular}{|c|c|c|c|c|c|c|}
\hline To visit freind and relatives & .806 & .756 & & & & \\
\hline To exchange custom and traditions & .734 & .621 & & & & \\
\hline $\begin{array}{l}\text { To live or stay temporarily with local } \\
\text { community }\end{array}$ & .655 & .607 & & & & \\
\hline Enhancing Social & & & 2.07 & $11.45 \%$ & 2.18 & 1.02 \\
\hline To increase my social status & .880 & .854 & & & & \\
\hline $\begin{array}{l}\text { To visit a destination that would impress } \\
\text { my friends and family }\end{array}$ & .878 & .805 & & & & \\
\hline Fullfilling Prestige & & & 1.39 & $7.76 \%$ & 3.32 & .847 \\
\hline To satisfy the desire to be somewhere else & .666 & .626 & & & & \\
\hline $\begin{array}{l}\text { To fulfill my dream of visiting a foreign } \\
\text { land/country }\end{array}$ & .705 & .736 & & & & \\
\hline $\begin{array}{l}\text { To have enjoyable time with my travel } \\
\text { companion(s) }\end{array}$ & .691 & .735 & & & & \\
\hline Escaping from the Daily Routine & & & 1.14 & $6.35 \%$ & 2.69 & .966 \\
\hline To be away from home & .845 & .752 & & & & \\
\hline To seek solitude in a foreign land & .770 & .698 & & & & \\
\hline Total Variance & $70.26 \%$ & & & & & \\
\hline
\end{tabular}

\subsection{Descriptive Statistic Analysis of Tourists' Perception on Destination Loyalty}

A descriptive statistic analysis was applied to identify the most important dimensions of tourists' perception on destination loyalty. As showed in Table 5, the statement of "Im willing to return to Malaysia in the future" obtained the highest mean value (4.15), followed by "I am willing to recommend Malaysia to family and friends as a holiday destination" (4.03). It can be concluded that respondents of this study intend to revisit and recommend Malaysia to family and friends as a holiday destination in future. According to literature, both revisit intention and recommendation are indicators of destination loyalty. This study also revealed that the image of Malaysia was identified as an important dimension for repeat visitors with the mean score of 3.96.

Table 5. Mean value of tourists' perception on destination loyalty

\begin{tabular}{lll}
\hline Statements & Mean & Std. Deviation \\
\hline $\begin{array}{l}\text { I am wiling to return to Malaysia in the future. } \\
\text { I am willing to recommend Malaysia to family and }\end{array}$ & 4.15 & .743 \\
friends as a holiday destination. & & .919 \\
$\begin{array}{l}\text { I have wonderful image of Malaysia as a holiday } \\
\text { destination. }\end{array}$ & 3.96 & .819 \\
$\begin{array}{l}\text { I visit new destinations other than those that I } \\
\text { previously visited in Malaysia. }\end{array}$ & 3.66 & .926 \\
$\begin{array}{l}\text { I feel I am very loyal to Malaysia as a destination } \\
\text { choice. }\end{array}$ & 3.60 & .915 \\
$\begin{array}{l}\text { Compared to my last visit, I spend more money in } \\
\text { this current visit. }\end{array}$ & 3.43 & .921 \\
$\begin{array}{l}\text { Compared to my last visit to Malaysia, I stay } \\
\text { longer period in the current visit. }\end{array}$ & 3.32 & 1.02 \\
$\begin{array}{l}\text { I always return to the same destinations that I } \\
\text { previously visited in Malaysia. }\end{array}$ & 2.85 & .934 \\
$\begin{array}{l}\text { Compared to my last visit, I come with bigger } \\
\text { companions in the current visit. }\end{array}$ & 2.61 & 1.08 \\
\hline
\end{tabular}

\section{Conclusions}

This paper has investigated and presented the influential factors of repeat visitors in East Malaysia, Sabah. The empirical results of this study highlight the key factors influencing repeat visitors to return to Sabah. It provides the ground to understand what motivates repeat visitors regarding revisit intention. Destination attributes that reflect Sabah as a tourist destination were examined. In this sense, "destination image", "modern environment", 
and "weather \& natural attractions" were underlined as the main factors to revisit Sabah. "Destination image" was the most important factor for repeat visitors of Sabah. In other words, it seems freindliness of local people, ability to communicate with local community, local foods as well as good value for money (destination image) are the main destination attributes that manifest Sabah's image as a tourist destination. Hence, destination managers should improve destination image of Sabah which affect repeat visitors' loyalty. Chen and Tsai (2007) pointed that "endeavors to build or improve the image of a destination facilitate loyal visitors revisiting or recommending behaviors..." (p.1121).

With regards to repeat visitors' motives to Sabah, "relaxation \& recreation", "enhance relation", "enhance social", "fullfiling prestige", and "escaping from the daily routine" were identified as imperative factors for revisit intention. "Relaxation \& recreation" (to relax physically, to relax spiritually, to participate in new activities, to find thrills and excitement, to sightsee touristic spots and to appreciate natural resources) were found as significant motives for repeat visitors. This is because Sabah is rich with resources and attractions in terms of nature, culture, adventure and beautiful beaches that provide destinations for relaxation and recreation.

In terms of destination loyalty, this study reveals that repeat visitors intend to revisit as well as recommend Sabah as a holiday destination in future. Previous research has shown that "tourists' positive experience of service products and other resources provided by tourism destination could produce repeat visits as well as positive WOM effects to friends and/or relatives" (Chi \& $\mathrm{Qu}, 2008$, p. 625). For this reason, appropriate marketing strategies should be intensified to further develop this market segment. Consequently, destination managers should consider destination attributes that suggest Sabah as a repeat tourism destination to enhance destination loyalty and achieve competitive advantages. As this study only focused on international repeat visitors, it is suggested that future research examine domestic repeat visitors to identify factors that influence their revisit intention.

\section{Acknowledgements}

This paper was part of an ongoing research, received primary support from Universiti Sains Malaysia's grant no. 1001/PPBGN/816149 and partial support from grant no. 1001/PTS/8660013.

\section{References}

Akama, J. S., \& Kieti, D. M. (2003). Measuring tourist satisfaction with Kenya's wildlife safari: a case study of Tsavo West National Park. Tourism management, $24(1)$, http://dx.doi.org/10.1016/S0261-5177(02)00044-4

Alexandris, K., Kouthouris, C., \& Meligdis, A. (2006). Increasing customers' loyalty in a skiing resort: The contribution of place attachment and service quality. International Journal of Contemporary Hospitality Management, 18(5), 414-425. http://dx.doi.org/10.1108/09596110610673547

Baker, D. A., \& Crompton, J. L. (2000). Quality, satisfaction and behavioral intentions. Annals of tourism research, 27(3), 785-804. http://dx.doi.org/10.1016/S0160-7383(99)00108-5

Bigne, J. E., Sanchez, I., \& Andreu, L. (2009). The role of variety seeking in short and long run revisit intentions in holiday destinations. International Journal of Culture, Tourism and Hospitality Research, 3(2), 103-115.

Bigne, J. E., Sanchez, M. I., \& Sanchez, J. (2001). Tourism image, evaluation variables and after purchase behaviour: inter-relationship. Tourism management, $607-616$. http://dx.doi.org/10.1016/S0261-5177(01)00035-8

Boonajsevee, B. (2005). Relationship marketing: Loyalty intentions in new era of Thai bank marketing. Fort Lauderdale, FL: Nova Southeastern University.

Buttle, F. (1996). Relationship marketing: theory and practice. Sage Publications Ltd.

Campo, S., \& Yague, M. J. (2008). Tourist loyalty to tour operator: effects of price promotions and tourist effort. Journal of Travel Research, 46(3), 318-326. http://dx.doi.org/10.1177/0047287507303975

Casielles, R. V., Alvarez, L. S., \& Martin, A. M. D. (2005). Trust as a key factor in successful relationships between consumers and retail service providers. The Service Industries Journal, 25(1), 83-101. http://dx.doi.org/10.1080/0264206042000302423

Chen, C. F., \& Tsai, D. C. (2007). How destination image and evaluative factors affect behavioral intentions? Tourism management, 28(4), 1115-1122. http://dx.doi.org/10.1016/j.tourman.2006.07.007 
Chen, J. S., \& Gursoy, D. (2001). An investigation of tourists destination loyalty and preferences. International $\begin{array}{lllll}\text { Journal of Contemporary Hospitality } & \text { Management, } & \text { 13(2), } & \text { 79-85. }\end{array}$ http://dx.doi.org/10.1108/09596110110381870

Chi, C. G. Q., \& Qu, H. (2008). Examining the structural relationships of destination image, tourist satisfaction and destination loyalty: An integrated approach. Tourism management, 29(4), 624-636. http://dx.doi.org/10.1016/j.tourman.2007.06.007

Cronin, J. J., Brady, M. K., \& Hult, G. T. M. (2000). Assessing the effects of quality, value, and customer satisfaction on consumer behavioral intentions in service environments. Journal of retailing, 76(2), 193-218. http://dx.doi.org/10.1016/S0022-4359(00)00028-2

Crotts, J. C. (1993). Personality correlates of the novelty seeking drive. Journal of Hospitality and Leisure Marketing, 1, 7-29. http://dx.doi.org/10.1300/J150v01n03_03

Darnell, A. C., \& Johnson, P. S. (2001). Repeat visits to attractions: a preliminary economic analysis. Tourism management, 22(2), 119-126. http://dx.doi.org/10.1016/S0261-5177(00)00036-4

Fallon, P., \& Schofield, P. S. (2003). "Just trying to keep the customer satisfied": a comparison of models used in the measurement of tourist satisfaction. In M. Uysal \& J. A. Williams (Eds.), Current Issues and Development in Hospitality and Tourism Satisfaction (pp. 77-96). Binghamton, NY: The Haworth Hospitality Press.

Flambard-Ruaud, S. (2005). Relationship marketing in emerging economies: some lessons for the future. Vikalpa, $30(3), 53$.

Frochot, I., \& Hughes, H. (2000). HISTOQUAL: The development of a historic houses assessment scale. Tourism management, 21(2), 157-167. http://dx.doi.org/10.1016/S0261-5177(99)00045-X

Fuchs, M., \& Weiermair, K. (2003). New perspectives of satisfaction research in tourism destinations. Tourism Review, 58(3), 6-14. http://dx.doi.org/10.1108/eb058411

Fyall, A., Callod, C., \& Edwards, B. (2003). Relationship Marketing: The Challenge for Destinations. Annals of tourism research, 30(3), 644-659. http://dx.doi.org/10.1016/S0160-7383(03)00046-X

Gotlieb, J. B., Grewal, D., \& Brown, S. W. (1994). Consumer satisfaction and perceived quality: complementary or divergent constructs? Journal of Applied Psychology, 79(6), 875-885. http://dx.doi.org/10.1037/0021-9010.79.6.875

Hair, J. F., Anderson, R. E., Tatham, R. L., \& Black, W. C. (1995). Multivariate Data Analysis: With Readings (4th ed.). Upper Saddle River, NJ: Prentice Hall.

Hsu, C., Killion, L., Brown, G., Gross, M., \& Huang, S. (2008). Tourism marketing: An Asian-Pacific perspective. Milton, Australia: John Wiley \& Sons

Hui, T. K., Wan, D., \& Ho, A. (2007). Tourists' satisfaction, recommendation and revisiting Singapore. Tourism management, 28(4), 965-975. http://dx.doi.org/10.1016/j.tourman.2006.08.008

Jang, S., \& Feng, R. (2007). Temporal destination revisit intention: The effects of novelty seeking and satisfaction. Tourism management, 28(2), 580-590. http://dx.doi.org/10.1016/j.tourman.2006.04.024

Jayarman, K., Lin, S. K., Guat, C. L., \& Ong, W. L. (2010). Does Malaysian Tourism Attract Singaporeans to Revisit Malaysia? Journal of Business and Policy Research, 5(2), 159-179.

Kneesel, E., Baloglu, S., \& Millar, M. (2010). Gaming destination images: Implications for branding. Journal of Travel Research, 49(1), 68-78. http://dx.doi.org/10.1177/0047287509336474

Kozak, M. (2001). Repeaters' behavior at two distinct destinations. Annals of tourism research, 28(3), 784-807. http://dx.doi.org/10.1016/S0160-7383(00)00078-5

Kozak, M. (2003). Measuring tourist satisfaction with multiple destination attributes. Tourism Analysis, 3(4), 229-240. http://dx.doi.org/10.3727/108354203108750076

Lau, A. L. S., \& McKercher, B. (2004). Exploration versus acquisition: A comparison of first-time and repeat visitors. Journal of Travel Research, 42(3), 279-285. http://dx.doi.org/10.1177/0047287503257502

Lee, C. K., Lee, Y. K., \& Lee, B. K. (2005). Korea's destination image formed by the 2002 World Cup. Annals of tourism research, 32(4), 839-858. http://dx.doi.org/10.1016/j.annals.2004.11.006 
Lee, J., Graefe, A. R., \& Burns, R. C. (2004). Service quality, satisfaction, and behavioral intention among forest visitors. Journal of Travel \& Tourism Marketing, 17(1), 73-82. http://dx.doi.org/10.1300/J073v17n01_05

Li, J. W. J., \& Carr, N. (2004). Visitor Satisfaction. International journal of hospitality \& tourism administration, $5(3), 31-48$.

Lovelock, C., Vandermerwe, S., \& Lewis, B. (1996). Service marketing: A European perspective. London: Prentice Hall Europe.

Mat Som, A. P., Mostafavi Shiazi, S. F., Marzuki, A., \& Jusoh, J. (2011). A critical analysis of tourist satisfaction and destination loyalty. Journal of Global Management, 2(1), 178-183.

Milman, A., \& Pizam, A. (1995). The role of awareness and familiarity with a destination: The central Florida case. Journal of Travel Research, 33(3), 21-27. http://dx.doi.org/10.1177/004728759503300304

Mostafavi Shirazi, S. F., \& Mat Som, A. P. (2010). Relationship Marketing and Community Involvement: Two Significant Factors for Tourism Strategies. In C.A. Brebbia \& F.D. Pineda (Eds.), Sustainable Tourism IV (pp. 47-53). Southampton, UK: WIT Press. http://dx.doi.org/10.2495/ST100051

Mostafavi Shirazi, S. F., \& Mat Som, A. P. (2011). Destination Management and Relationship Marketing: Two Major Factors to Achieve Competitive Advantage. Journal of Relationship Marketing, 10(2), 76-87. http://dx.doi.org/10.1080/15332667.2011.577731

Niininen, O., Szivas, E., \& Riley, M. (2004). Destination loyalty and repeat behaviour: an application of optimum stimulation measurement. International Journal of Tourism Research, 6(6), 439-447. http://dx.doi.org/10.1002/jtr.511

Nwakanma, H., Jackson, A. S., \& Burkhalter, J. N. (2007). Relationship Marketing: An Important Tool For Success In The Marketplace. Journal of Business \& Economics Research (JBER), 5(2), 55-64.

Oppermann, M. (2000). Tourism destination loyalty. Journal of Travel Research, 39(1), 78-84. http://dx.doi.org/10.1177/004728750003900110

Pearson, P. H. (1970). Relationships between global and specified measures of novelty seeking. Journal of Consulting and Clinical Psychology, 34(2), 199-204. http://dx.doi.org/10.1037/h0029010

Petrick, J. F., \& Backman, S. J. (2002). An examination of the determinants of golf travelers' satisfaction. Journal of Travel Research, 40(3), 252-258. http://dx.doi.org/10.1177/004728750204000303

Petrick, J. F., Morais, D. D., \& Norman, W. C. (2001). An examination of the determinants of entertainment vacationers' intentions to revisit. Journal of Travel Research, 40(1), 41-48. http://dx.doi.org/10.1177/004728750104000106

Prayag, G., \& Ryan, C. (2010). The relationship between the "push"and "pull' factors of a tourist destination: the role of nationality-"an analytical qualitative research approach. Current Issues in Tourism, 14(2), 121-143. http://dx.doi.org/10.1080/13683501003623802

Rayan, C. (2002). From motivation to assessment. In C. Rayan (Ed.), The tourist experience (pp. 58-77). London: Continuum.

Reisinger, Y., \& Turner, L. (1998). Cross-cultural differences in tourism: A strategy for tourism marketers. Journal of Travel \& Tourism Marketing, 7(4), 79-106. http://dx.doi.org/10.1300/J073v07n04_05

Rittichainuwat, B. N., Qu, H., \& Brown, T. J. (2001). Thailand's international travel image: mostly favorable. The Cornell Hotel and Restaurant Administration Quarterly, 42(2), 82-95.

Ross, G. F. (1993). Ideal and actual images of backpacker visitors to Northern Australia. Journal of Travel Research, 32(2), 54-57. http://dx.doi.org/10.1177/004728759303200208

Shanka, T., Ali-Knight, J., \& Pope, J. (2002). Intrastate travel experiences of international students and their perceptions of Western Australia as a tourist destination. Tourism and Hospitality Research, 3(3), 245-256.

Shanka, T., Quaddus, M., \& Hossain, M. E. (2010). Understanding the antecedent factors of visitors' destination loyalty using partial least square: A Priminary Study of Cox's Bazar, Bangladesh. Paper presented at the ANZMAC Annual Conference 2010, Christchurch, New Zealand.

Sherrell, D. L., \& Bejou, D. (2007). Assessing the productivity of relationship marketing: Moving toward a paradigm. Journal of Relationship Marketing, 6(2), 3-7. http://dx.doi.org/10.1300/J366v06n02_02 
Shoemaker, S., \& Lewis, R. C. (1999). Customer loyalty: the future of hospitality marketing. International Journal of Hospitality Management, 18(4), 345-370. http://dx.doi.org/10.1016/S0278-4319(99)00042-0

Tasci, A. D. A., \& Gartner, W. C. (2007). Destination image and its functional relationships. Journal of Travel Research, 45(4), 413-425. http://dx.doi.org/10.1177/0047287507299569

Um, S., Chon, K., \& Ro, Y. H. (2006). Antecedents of revisit intention. Annals of tourism research, 33(4), 1141-1158. http://dx.doi.org/10.1016/j.annals.2006.06.003

Wang, Y. C., Lin, W. R., Yeh, P. H., \& Lui, C. R. (2011). The role of destination image in formation of destination loyalty at leisure farm: Difference between first-time and repeat visitors. Paper presented at the 7th CPTHL Symposium Chiang Mai, Thailand.

Weaver, D., \& Lawton, L. (2002). Tourism Management (2nd ed.). Milton, Qld: Jhon Wiley \& Sons Australia, Ltd.

Williams, C., \& Buswell, J. (2003). Service quality in leisure and tourism. CABI. http://dx.doi.org/10.1079/9780851995410.0000

Wong, C. S., \& Kwong, W. Y. (2004). Outbound tourists' selection criteria for choosing all-inclusive package tours. Tourism management, 25(5), 581-592. http://dx.doi.org/10.1016/j.tourman.2003.06.002

Yoon, Y., \& Uysal, M. (2005). An examination of the effects of motivation and satisfaction on destination loyalty: a structural model. Tourism management, 26(1), 45-56. http://dx.doi.org/10.1016/j.tourman.2003.08.016

Yuksel, A. (2001). Managing customer satisfaction and retention: A case of tourist destinations, Turkey. Journal of Vacation Marketing, 7(2), 153-168. http://dx.doi.org/10.1177/135676670100700205

Zabkar, V., Brenc, M. M., \& Dmitrovic, T. (2010). Modelling perceived quality, visitor satisfaction and behavioural intentions at the destination level. Tourism management, 31(4), 537-546. http://dx.doi.org/10.1016/j.tourman.2009.06.005 